\title{
TAHAP-TAHAP PROSES KEPERAWATAN \\ DALAM PENGOPTIMALAN ASUHAN KEPERAWATAN
}

\author{
Kristina N Tampubolon \\ kristinatampubolon381@gmail.com
}

\begin{abstract}
ABSTRAK
Perawat sebagai suatu profesi dapat mempertahankan dan meningkatkan mutu asuhan keperawatan maka jawabannya adalah dengan adanya standar. Standar merupakan level kinerja yang diinginkan dan yang dapat dicapai dimana kerja aktual dapat dibandingkan. . Dokumentasi asuhan keperawatan mencakup pernyataan dan pelaporan tentang pengkajian (pengumpulan data), diagnosis keperawatan, rencana tindakan keperawatan, tindakan dan evaluasi keperawatan.Dokumentasi yang efektif menjamin kesinambungan pelayanan, menghemat waktu, dan meminimalisasi resiko kesalahan Fator-faktor yang berhubungan dengan perilaku pendokumentasian adalah pengetahuan, sikap, beban kerja, saran, insentif dan kepemimpinan. Asuhan keperawatan adalah suatu pendekatan untuk pemecahan masalah pada pasien dengan memberikan pelayanan keperawatan. Sejauh ini perawat tidak sepenuhnya melakukan asuhan keperawatan sesuai dengan SOP.Sedangkan, Proses Keperawatan adalah suatu metode yang sistematis dan terorganisasi dalam pemberian asuhan keperawatan, yang difokuskan pada reaksi dan respons unik individu pada suatu kelompok atau perorangan terhadap gangguan kesehatan yang dialami, baik actual maupun potensial.
\end{abstract}

Kata Kunci : Proses keperawatan,Tahap-tahap proses keperawatan,Optimalisasi Asuhan Keperawatan,Perawat. 


\section{A. LATAR BELAKANG}

Keperawatan merupakan suatu bentuk pelayanan profesional bersifat humanistik, menggunakan pendekatan holistik, dilakukan berdasarkan ilmu dan kiat keperawatan, berorientasi kepada kebutuhan objektif klien. Standar merupakan level kinerja yang diinginkan dan yang dapat dicapai dimana kerja aktual dapat dibandingkan. la memberikan petunjuk kinerja mana yang tidak cocok atau tidak dapat diterima. Standar praktek keperawatan adalah pernyataan tentang apa yang dibutuhkan oleh registered nurse untuk dijalankan sebagai professional keperawatan. Secara umum, standar ini mencerminkan nilai profesi keperawatan dan memperjelas apa yang diharapkan profesi keperawatan kepada anggotanya.

Praktek keperawatan mengacu pada standar professional keperawatan dan menggunakan etika keperawatan sebagai tuntutan utama. Perawat dituntut untuk selalu melaksanakan asuhan keperawatan yang benar atau rasional.Oleh karena itu,perawat harus mengoptimalkan proses keperawatan. Proses asuhan keperawatan merupakan tugas dan kewajiban seorang perawat dari pasien datang sampai pasien pulang, dimulai dengan pengkajian secara menyeluruh, kemudian menegakkan diagnosa keperawatan dari data pengkajian tersebut, serta melaksanakan intervensi, implementasi dan evaluasi keefektifan diagnosa awal yang sudah ditegakkan.

Proses tahap-tahap keperawatan tadi dituang dalam agenda yang bernama dokumentasi keperawatan.Dokumentasi secara umum merupakan suatu catatan otentik atau semua warkat asli yang dapat dibuktikan atau dijadikan bukti dalam persoalan hukum. Dokumentasi keperawatan merupakan bukti pencatatan dan pelaporan yang dimiliki perawat dalam melakukan catatan keperawatan yang berguna untuk kepentingan klien, perawat dan tim kesehatan dalam memberikan pelayanan kesehatan dengan dasar komunikasi yang akurat dan baik secara tertulis dengan tanggung jawab perawat.

Pendokumentasian asuhan keperawatan adalah proses pelaksanaan pencatatan asuhan keperawatan yakni dari pengkajian saat masuk sampai pasien dinyatakan sehat. Diagnosis yang diangkat berdasarkan masalah yang ditemukan, perencanaan keperawatan, tindakan yang dilakukan serta evaluasi dari proses asuhan keperawatan yang diberikan. 
Dari hasil wawancara dengan beberapa perawat didapatkan bahwa mereka kurang dalam pendokumentasian disebabkan faktor kepemimpinan (kepala ruangan), kepemimpinan dirasakan kurang memberikan pengawasan dan kepala ruangan kurang adil dalam pembagian shift, tidak ada pengawasan serta tidak ada penghargaan tambahan apabila perawat melakukan pendokumentasian dengan baik, hasil asuhan keperawatan pada klien tiap harinya lebih kurang sama,serta jumlah perawat yang sedikit dibandingkan dengan jumlah pasien.

Sedangkan untuk asuhan keperawatan adalah suatu pendekatan untuk pemecahan masalah yang memampukan perawat untuk mengatur dan memberikan asuhan keperawatan. Standar asuhan yang tercantum dalam Standar Praktik Klinis Keperawatan terdiri dari lima fase asuhan keperawatan: 1) Pengkajian; 2) Diagnosa; 3) Perencanaan; 4) Implementasi; dan 5) Evaluasi. Salah satu manfaat dari penerapan asuhan keperawatan yang baik adalah meningkatkan mutu dan kualitas pelayanan dalam bidang keperawatan.

Oleh karena itu,jelaslah sudah tahap-tahap proses keperawatan mempengaruhi keoptimalan asuhan keperawatan itu sendiri.Dikarenakan, proses keperawatan adalah satu pendekatan untuk pemecahan masalah yang memampukan perawat untuk mengatur dan memberikan asuhan keperawatan.

\section{B. METODE}

Dalam karya ilmiah ini penulis menggunakan metode kepustakaan dengan cara membaca berbagai sumber seperti : buku,ebook,jurnal,karya ilmiah,dan sumber lainnya yang dapat dipercaya dikarenakan agar setiap pembaca tidak dipusingkan dengan artikel-artikel yang kurang efektif dan belum dianalisis kebenarannya.Sumber-sumber yang dibaca dan dicari penulis juga berkenaan dengan materi permasalahan yang akan dibahas oleh penulis sehingga sistematis yang dibahas selalu berhubungan dan dapat mempermudah pemahaman pembaca. 


\section{HASIL}

Proses keperawatan adalah aktivitas yang mempunyai maksud yaitu praktik keperawatan yang dilakukan dengan cara yang sistematik. Selama melaksanakan proses keperawatan, perawat menggunakan dasar pengetahuan yang komprehensif untuk mengkaji status kesehatan klien, membuat penilaian yang bijaksana dan mendiagnosa, mengidentifikasi hasil akhir kesehatan klien dan merencanakan, menerapkan dan mengevaluasi tindakan keperawatan yang tepat guna mencapai hasil akhir tersebut.

Proses keperawatan dituang dalam dokumentasi keperawatan dimana dokumentasi keperawatan adalah suatu catatan yang memuat seluruh data yang dibutuhkan untuk menentukan diagnosis keperawatan, perencanaan keperawatan, tindakan keperawatan, dan penilaian keperawatan yang disusun secara sistematis, valid, dan dapat dipertanggungjawabkan secara moral dan hokum.

Adapun tujuan proses keperawatan adalah sebagai berikut:

a) Mempraktikkan metode pemecahan masalah dalam praktik keperawatan.

b) Menggunakan standar untuk praktik keperawatan.

c) Memperoleh metoda yang baku dan sesuai, rational dan sistematis dalammemberikan asuhan keperawatan pada pasien.

d) Memperoleh metoda yang dapat digunakan dalam segala situasi.

e) Memperoleh hasil asuhan keperawatan dengan kualitas tinggi.

Pemberi asuhan keperawatan adalah tugas perawat pelaksana.Perawat pelaksana bertugas memberikan asuhan keperawatan, membantu penyembuhan, membantu memecahkan masalah pasien dibawah pengawasan dokter atau kepala ruang. Pada dasarnya juga proses keperawatan adalah suatu metode ilmiah yang sistematis dan terorganisir untuk memberikan asuhan keperawatan kepada klien.

Proses keperawatan sangat penting karena berfungsi sebagai kerangka fikir untuk menjalankan fungsi dan tanggung jawab keperawatan dalam lingkup yang luas. Proses keperawatan juga berfungsi sebagai alat untuk mengenal masalah pasien, menyusun perencanaan secara sistematik, melaksanakan tindakan dan menilai hasil tindakan. 
Ada beberapa manfaat proses keperawatan yang bermanfaat bagi klien, perawat, institusi pelayanan, dan masyarakat (lingkungan),yakni:

1. Manfaat bagi Klien Klien mendapatkan pelayanan keperawatan yang berkualitas, efektif, dan efisien. Asuhan keperawatan yang diberikan telah diseleksi sesuai dengan kebutuhan klien melalui penelusuran data, rumusan permasalahan yang matang, diagnosis keperawatan yang epat, rencana yang terarah, tindakan yang sesuai dengan rencana, dan penilian yang terus-menerus.

2. Manfaat bagi Tenaga KeperawatanProses keperawatan akan meningkatkan kemandirian tenaga keperawatan dan pelaksanaan asuhan keperawatan dan tidakbergantung pada profesi lain. Proses ini juga memberi kepuasan yang optimal bagi tenaga keperawatan yang berhasil dalam pelaksanaan asuhan keperawatannya.

3. Manfaat bagi InstitusiInstitusi pelayanan akan merasakan manfaat, antara lain klien merasa puas, cepat sembuh, pelayanan yang bermutu sekaligus merupakan promosi institusi tersebut. Dengan demikian, klien meningkat dan keuntungan pun meningkat. Citra institusi bertambah baik di mata masyarakat.

\section{PEMBAHASAN}

Proses keperawatan pertama kali diperkenalkan pada tahun 1950-an sebagai proses tiga tahap yaitu pengkajian, perencanaan, dan evaluasi yang berdasarkan pada metode ilmiah yaitu mengobservasi, mengukur, mengumpulkan data, dan menganalisis temuan-temuan tersebut. Seiring perkembangan keperawatan, berbagai penemuan dalam dunia keperawatan pun diperkenalkan yakni langkah-langkah pada proses keperawatan adalah mengumpulkan informasi, menentukan diagnosa keperawatan aktual atau potensial, mengidentifikasi hasil yang dapat diukur dan menggambarkan respon pasien, mengembangkan intervensi individu yang bertujuan mencapai hasil, mengevaluasi kemajuan pencapaian tujuan, menilai rencana keperawatan didasarkan pada penggunaan proses keperawatan.Maka dari itu perlu bagi perawat mengetahui tahap-tahap dalam proses keperawatan,antara lain : 


\section{a) Pengkajian}

Pengkajian adalah tahap awal dari proses keperawatan dan merupakan proses yang sistematis dalam pengumpulan data dari berbagai sumber data untuk mengevaluasi dan mengidentifikasi status kesehatan. Pada tahap ini semua data dikumpulkan secara sistematis guna menentukan kesehatan klien. Pengkajian harus dilakukan secara komprehensif terkait dengan aspek biologis, psikologis, social maupun spiritual klien.

Tujuan pengkajian adalah untuk mengumpulkan informasi dan membuat data dasar klien. Langkah pertama dari proses keperawatan yaitu pengkajian, dimulai perawat menerapkan pengetahuan dan pengalaman untuk mengumpulkan data tentang klien. Pengkajian dan pendokumentasian yang lengkap tentang kebutuhan pasien dapat meningkatkan efektivitas asuhan keperawatan yang diberikan, melalui hal-hal berikut:

Menggambarkan kebutuhan pasien untuk membuat diagnosis keperawatan dan menetapkan prioritas yang akurat sehingga perawat juga dapat menggunakan waktunya dengan lebih efektif.

Memfasilitasi perencanaan intervensi.

Menggambarkan kebutuhan keluarga dan menunjukkan dengan tepat faktor-faktor yang akan meningkatkan pemulihan pasien dan memperbaiki perencanaan pulang.

Memenuhi obligasi profesional dengan mendokumentasikan informasi pengkajian yang bersifat penting.

\section{b) Diagnosa Keperawatan}

Diagnosa keperawatan adalah langkah kedua dari proses keperawatan yang menggambarkan penilaian klinis tentang respon individu, keluarga, kelompok maupun masyarakat terhadap permasalahan kesehatan baik aktual maupun potensial. Dimana perawat mempunyai lisensi dan kompetensi untuk mengatasinya. Diagnosis keperawatan melibatkan proses berpikir kompleks tentang data yang dikumpulkan dari klien, keluarga, rekam medik, dan pemberi pelayanan kesehatan yang lain.Adapun tahapannya, yaitu :

1) Menganalisis dan menginterpretasi data.

2) Mengidentifikasi masalah klien.

3) Merumuskan diagnosa keperawatan.

4) Mendokumentasikan diagnosa keperawatan. 


\section{c) Perencanaan}

Perencanaan keperawatan adalah bagian dari fase pengorganisasian dalam proses keperawatan sebagai pedoman untuk mengarahkan tindakan keperawatan dalam usaha membantu, meringankan, memecahkan masalah atau untuk memenuhi kebutuhan pasien. Tahapan ini perawat merencanakan suatu tindakan keperawatan agar dalam melakukan perawatan terhadap pasien efektif dan efisien. Adapun tahapannya, yaitu :

1) Mengidentifikasi tujuan klien.

2) Menetapkan hasil yang diperkirakan.

3) Memilih tindakan keperawatan.

4) Mendelegasikan tindakan.

5) Menuliskan rencana asuhan keperawatan

\section{d) Implementasi}

Implementasi keperawatan adalah pengelolaan dan perwujudan dari rencana keperawatan yang telah disusun pada tahap perencanaan. Tahapan ini perawat mencari inisiatif dari rencana tindakan untuk mencapai tujuan yang spesifik. Tahap pelaksanaan dimulai setelah rencana tindakan disusun dan ditunjukan pada nursing orders untuk membantu klien mencapai tujuan yang telah ditetapkan, yang mencakup peningkatan kesehatan, pencegahan penyakit, pemulihan kesehatan dan memfasilitasi koping.

Implementasi yang merupakan komponen dari proses keperawatan adalah kategori dari perilaku keperawatan dimana tindakan yang diperlukan untuk mencapai tujuan dan hasil yang diperkirakan dari asuhan keperawatan yang dilakukan dan diselesaikan.

Tahapannya yaitu :

1) Mengkaji kembali klien/pasien.

2) Menelaah dan memodifikasi rencana perawatan yang sudah ada.

3) Melakukan tindakan keperawatan. 


\section{e) Evaluasi Keperawatan}

Evaluasi keperawatan adalah kegiatan yang terus menerus dilakukan untuk menentukan apakah rencana keperawatan efektif dan bagaimana rencana keperawatan dilanjutkan, merevisi rencana atau menghentikan rencana keperawatan. Penilaian adalah tahap yang menentukan apakah tujuan tercapai. Evaluasi selalu berkaitan dengan tujuan, apabila dalam penilaian ternyata tujuan tidak tercapai, maka perlu dicari penyebabnya. Tahapan ini perawat melakukan tindakan intelektual untuk melengkapi proses keperawatan yang menandakan seberapa jauh diagnosa keperawatan, rencana tindakan, dan pelaksanaannya sudah berhasil dicapai.

Langkah evaluasi dari proses keperawatan mengukur respons klien terhadap tindakan keperawatan dan kemajuan klien kearah pencapaian tujuan.

Adapun tahapannya, yaitu :

1) Membandingkan respon klien dengan kriteria.

2) Menganalisis alasan untuk hasil dan konklusi.

3) Memodifikasi rencana asuhan.

4) Syarat Dokumentasi Keperawatan.

Dalam dunia keperawatan, konsep optimalisasi Proses Keperawatan adalah hal UTAMA yang harus Anda pahami.Inti dari Proses Keperawatan sederhana. Anda membutuhkan optimalisasi Proses Keperawatan supaya:

$\checkmark$ Bermanfaat tinggi untuk klien

$\checkmark$ Asuhan Keperawatan diterima, bermutu dan dapat dipertanggungjawabkan secara ilmiah

$\checkmark$ Merangsang partisipasi pasien dalam kemandirian perawatan (self care)

$\checkmark$ Ada keberlanjutan asuhan

$\checkmark$ Terhindar dari mal-praktik

Oleh karena itu,jelaslah sudah bagaimana tahapan komunikasi mempengaruhi optimalisasi asuhan keperawatan. 


\section{E. PENUTUP}

Proses keperawatan adalah salah satu metoda efektif pemecahan masalah yang dilakukan perawat terhadap klien dengan pendekatan metodologi ilmiah. Asuhan keperawatan dapat dipertanggungjawabkan berdasarkan substansi ilmiah yaitu logis, sistimatis, dinamis dan terstruktur. Seiring perkembangan keperawatan, berbagai penemuan dalam dunia keperawatan pun diperkenalkan yakni langkah-langkah pada proses keperawatan adalah mengumpulkan informasi, menentukan diagnosa keperawatan aktual atau potensial, mengidentifikasi hasil yang dapat diukur dan menggambarkan respon pasien, mengembangkan intervensi individu yang bertujuan mencapai hasil, mengevaluasi kemajuan pencapaian tujuan, menilai rencana keperawatan didasarkan pada penggunaan proses keperawatan.

\section{F. DAFTAR PUSTAKA}

Aziz,A.H. (2017). Hubungan Antara Pendidikan Dan Pengetahuan Perawat Dengan Kelengkapan Pendokumentasian Askep Di Ruang Rawat Inap Rsud Dr. R. Goeteng Taroenadibrata Purbalingga. Bachelor Thesis,Universitas Muhammadiyah Purwokerto.

Bumulo, M. I.et.al. (2017). Pengaruh Manajemen Model Asuhan Keperawatan Profesional Tim Terhadap Kualitas Pelayanan Keperawatan Di Bangsal Pria Rsud Datoe Binangkang Kabupaten Bolaang Mongondow. e-Jurnal Keperawatan (e-Kp),5(2), 1-6.

Kasim, M.et.al. (2016). Peningkatan Kualitas Pelayanan Dan Pendokumentasian Asuhan. NurseLine Journal,1(1), 63-72.

Mulyanti,D.Y.(2017). Dokumentasi Keperawatan. Jakarta: Pusdik SDM Kesehatan. 
Prastanti,D.W.(2012). Hubungan Kelengkapan Dokumentasi Keperawatan Dengan Mutu Pelayanan Keperawatan Di Ruang Melati Rsud Prof. Margono Soekarjo Purwokerto. Bachelor Thesis,Universitas Muhammadiyah Purwokerto.

Rinawati, Prema. (2018).Kompetensi Perawat Dalam Merumuskan Diagnosa Keperawatan Pada Pasien Di Ruang Rawat Inap Rsud Tugurejo Semarang. Undergraduate thesis, Universitas Muhammadiyah Semarang.

Ryandini,T.P.(2018). Pengembangan Instrumen Evaluasi Asuhan Keperawatan Dalam Format Catatan Perkembangan Pasien Terintegrasi Pada Pasien Diabetes Mellitus. Undergraduate thesis, Universitas Airlangga.Tidak Dipublikasikan.

Simamora. R. H. (2008) The correlation of ward chief's giving direction and command and the performance of on-duty nurses at Jember dr. Subandi general hospital inpatient wards. jurnal Administrasi dan Kebijakan Kesehatan, (https://fkm.unair.ac.id/jurnal-administr)

Simamora, R. H. (2019). Development of Guidelines for Applying appropriate Patient Identification to Achieve Patient Safety Goal INC2019 12th International Nursing Conference. 2019.10455 - 455 (1 pages) UCI(KEPA) : 1410-ECN-0101-2019-512-001224337.

Supratti.et.al. (2016). Pendokumentasian Standar Asuhan Keperawatan. Jurnal Kesehatan MANARANG,2(1), 44-51.

Wulandini, P.et.al. (2016). Faktor-Faktor Yang Berhubungan Dengan. Ners Jurnal Keperawatan,12(2), 131-142.

Yeni, F. (2014). Pengaruh Pelatihan Proses Keperawatan terhadap Dokumentasi. NERS JURNAL KEPERAWATAN,10(1), 20-27. 
